\title{
Analysis of the Relationship Between Stress and Organizational Commitment in Employees: A Meta-Analysis Study
}

\author{
Öznur Tulunay Ateş ${ }^{1}$, Neslin İhtiyaroğlu ${ }^{2}$ \\ ${ }^{1}$ Assistant Professor, Mehmet Akif Ersoy University, Burdur, Turkey \\ ${ }^{2}$ Assistant Professor, Kırıkkale University, Kırıkkale, Turkey \\ Correspondence: Neslin İhtiyaroğlu, Kırıkkale University, Kırıkkale, Turkey
}

Received: October 19, 2018

Accepted: November 16, $2018 \quad$ Online Published: December 21, 2018

doi:10.11114/jets.v7i1.3702

URL: https://doi.org/10.11114/jets.v7i1.3702

\begin{abstract}
This research aims to investigate the relationship of stress and organizational commitment in employees with meta-analysis method. In the literature review, 22 studies and 42 comparisons were found which meet the determined criteria. "Fisher z" value was used to calculate impact size values and impact direction and overall impact of the research were analysed with random impact model. As a result of the analysis; it was determined that stress have a weak positive relationship impact on organizational commitment. In addition, it was also determined that there is a negative and weak relationship impact between stress and affective commitment; positive and weak relationship impact between stress and normative commitment and positive and small relationship impact between stress and continuance commitment in employees. In the research, it was seen that the impact of stress on organizational commitment vary according to the sector that employees work in. in the analyses, it was determined that there is a positive impact in health and tourism and a negative impact in education and the impact size is weak in health and small in tourism and education. Based on the research results, it can be said that new researches are required about how and why the relationships between stress and organizational commitment in employees vary.
\end{abstract}

Keywords: stress, stress in employees, organizational stress, job stress, organizational commitment, meta-analysis

\section{Introduction}

Individual's being or not being effective and efficient in daily life and business life is closely related to many individual and environmental factors. While positive factors increase effectiveness and efficiency of individuals by revealing positive experiences in individuals, negative factors cause that individuals' quality of life decreases and therefore their effectiveness and efficiency decrease. One of these factors which affect individuals' quality of life, stress negatively affects individuals physically, behaviourally and psychologically as a part of daily life and this may be reflected on state of mind and even health of the individuals. For that reason, it is important to raise awareness of individuals about factors such as stress which affect their psychology and physiology.

As there are many variables which affect and are affected by stress, it is not possible to explain stress with a single definition. Selye (1980: 6) used stress as a concept for the first time and described it as the specific reactions of the organism to stimulants which cause change. In addition, stress may be defined as individual's wellbeing is in danger as a result of pushing and crossing the individual limits with the impact of environmental factors (Z. Baltaş \& A. Baltaş, 2006; Folkman, Lazarus, Gruen \& DeLongis, 1986); individual's making effort beyond his physical and psychological limits because of conditions which are not compatible with his nature (Cüceloğlu, 1998); the reaction which occurs when the individual's real world and expectations do not match (Magnuson, 1990) and a state of tension which bothers the individual both psychologically and physiologically (Ünsal, 2012). Besides, stress may also be discussed with its stimulant and reaction aspects and described as the change in the organism caused by the harmful impacts of individual and environmental factors as a factor or reaction which harms the organism as a stimulant (Lazarus \& Folkman, 1984). Based on the definitions on stress, it can be said that stress starts when the dangers caused by individual's interaction with his environment are perceived by the organism, this danger which affects the entire organism activates the individual more excessively than his motivated state and these actions cannot be controlled normally (Tutar, 2000).

All of the individuals who come across stress develop the same reactions to stress. These common reactions to stress are called "General Adaptation Syndrome" (Selye, 1975: 14). General Adaptation Syndrome is realized in three stages. The 
first stage is the alarm phase. In this first phase, the individual notices the source of the stress and displays first reactions against this source and individual's behavioural reactions are accompanied by physiological changes and individual's blood pressure and glycose level increase and his heart rate increases. If the individual's exposure to stimulant causing stress is extended, the second phase which is resistance starts. In this phase, the resistance of the body against the cause of stress increases and the individual makes an effort to get rid of the imbalance caused by the stress and go back to balance. If the individual could not go back to balance as a result of his efforts, the third phase, exhaustion starts. In this phase, the individual's energy for going back to balance runs out and the individual loses his resistance to the source of stress (Ross \& Altmaier, 1994).

Stress factors which causes the individual to come to the third phase, which is exhaustion, may be sourced from the individual's work life as well as his daily or private life. For that reason, the possibility that employees encounter stress factors caused by work life is quite high. This high possibility caused that various researches are carried out on the stress that employees experience. In researches on working individuals, stress is generally discussed within the context of organizational stress or work stress.

\subsection{Organizational Stress}

Organizational stress is a broad concept which includes organizational features that cause stress in employees and employee behaviours (Stinchcomb, 2004) and although it varies from employee to employee, it may be defined as the situation caused by the relationships among individual, organization and other employees and which cause that the individual goes out of normal functions (Arıkanlı \& Ulubaş, 2004). As employees' going out of normal functions would affect the efficiency and productivity of the employees negatively, it may play a role which may prevent achieving organizational objectives. For that reason, it is considered important that awareness level regarding organizational stress sources is high in terms of maintaining wellbeing of both employees and organizations.

Organizational stress may be caused by the structure of task, structure of authority, structure of production, structure of clustering, structure of role or cultural structure. Sub-dimensions of these sources can be listed as:

- Structure of task: Excessive work load, monotonous or boring work, inadequate salary, lack of promotion opportunities, long working hours and unsuitable working conditions

- Structure of authority: Lack of decision making ability, subordinates' inability to participate in decision making process, lack of authority, anxiety caused by responsibility, inadequate assessment processes

- Structure of productivity: Time pressure, lack of tools-instruments, individuals' abilities not compatible with the requirements of the work

- Structure of cluster: Unrest in working environment, conflicts with superiors-subordinates and colleagues, low social support and gossip at the workplace

- Structure of role: Incompatibility between the requirements of the work and employees' personality and uncertainty of roles

- Cultural structure: Different views in the working environments, lack of common values and norms, low status, morale and job satisfaction (Bertan, 2012).

The source of factors causing stress in the organization may be the lack of communication among employees, leaders' undemocratic behaviours or employees' not feeling safe in the organization (Palmer, Cary \& Kate, 2003). In addition, 24/7 working time in organizations, pressure towards quickly adapting to structural changes and expectations regarding high quality standards may also support formation of organization stress in employees (Manning \& Preston, 2003). The reason why there are so many factors affecting organizational stress is that each work has its own nature or each individual has a different process of giving meaning to the external world. For example; while long working hours is not a source of stress for teachers, it may be for doctors or while not being able to participate in decision making is a cause of stress for an employee, another employee may experience organizational stress based on low salary.

It can be said that job stress may be caused by factors related to the nature of the job and it can be explained by sub-dimensions such as specific tasks that constitute the job, the complexity of the job and job's including responsibilities on various dimensions (Cartwright \& Cooper, 1998). However, when the literature on job stress is reviewed, it is seen that organization stress dimensions are used to explain job stress and job stress (Ahmed \& Ramazan, 2013; Ergün \& Çelik, 2015; Gharib, Jamil, Ahmed \& Ghouse, 2016; Gül, Oktay \& Gökçe, 2008; Khatibi, Asadi \& Hamidi, 2009; Tekingündüz \& Kurtuldu, 2015) are organizational stress (Akhtar, 2011; Bhagat et al., 2010; Düzgün, 2014; Sullivan \& Bhagat, 1992; Şahin, 2014; Yiğit, 2009) are used in the same meaning and as interchangeably. For that reason, organizational stress and job stress are investigated with the theme of stress in employees in this research.

Although overall impact of stress is directed to the individual, organizational stress affects both the individual and many 
variables about the organization negatively. Especially the relationship between stress and organizational commitment in employees has been the subject of various researches (Akınaltuğ, 2003; Akpulat, Polat Üzümcü \& Karacan, 2016; Aydoğan, 2008; Düzgün, 2014; Efeoğlu \& Özgen, 2007; Erdilek Karabay, 2014; Ergün \& Çelik, 2013; Gül et al., 2008; Güngör Seyhan, 2015; İnan Yousuf, 2015; İncesu, 2011; K1lıç, Efeoğlu, Mimaroğlu \& Özgen, 2008; Köseoğlu Şalk, 2016; Pekerşen, 2015; Üzüm, 2010; Sökmen \& Şimşek, 2016; Şahin, 2014; Tekingündüz \& Kurtuldu, 2015; Turunç \& Erkuş, 2010; Yıldız, 2013; Yiğit, 2009). When the studies on stress and organizational commitment in employees are reviewed, it is seen that these researhes are carried out in various fields such as education (Aydoğan, 2008; Güngör Seyhan, 2015; Yıldız, 2013) health (Efeoğlu \& Özgen, 2007; Ergün \& Çelik, 2013; Gül et al., 2008; İncesu, 2011; Kılıç et al., 2008; Köseoğlu Şalk, 2016; Tekingündüz \& Kurtuldu, 2015), tourism (Akpulat et al., 2016; Düzgün, 2014; Pekerşen, 2015; Şahin, 2014; Yiğit, 2009), banking (Erdilek Karabay, 2014; Turunç \& Erkuş, 2010), sports (Kaplan, 2017; Üzüm, 2010) and media (İnan Yousuf, 2015) and different researchers in the same field (Aydoğan, 2008; Güngör Seyhan, 2015; Y1ldız, 2013) investigated this relationship with different sample groups as in education. All these studies can be considered as an indicator of the importance given to the stress and organizational commitment relationship in employees in every field.

\subsection{Organizational Commitment}

Organizational commitment is one of the most important variables that allows an organization to continue its existence. Organizational commitment can be defined as employees' determination level to achieve organizational targets (Caught \& Shadur, 2000); protecting the values of the organization and adopting its objectives (Meyer \& Allen, 1997); internalizing the values of the organization and the desire to remain in the organization to achieve its objectives (De Cotiis \& Summers, 1987); the process of employees' defining themselves with the organization and becoming a part of the organization (Balc1, 2003) and employees' efforts towards organizational objectives and values beyond the organization's expectations (Celep, 2000).

As organizational commitment is a variable which includes various commitment dimensions, it is classified in various forms by researchers. Etzioni (1961) classified organizational commitment as moral commitment, utilitarian commitment and alienating commitment; O'Reilly and Chatman (1986) classified it as adaptation commitment, identification commitment and internalization commitment; Wiener (1982) classified it as instrumental commitment and normative-moral commitment; Buchanan (1974) classified it as identification, hugging and loyalty commitment. In addition, the classification by Allen and Meyer (1990) as affective commitment, normative commitment and continuance commitment is one of the most used classifications in the organizational commitment literature.

While organizational commitment classification by Meyer and Allen (1984) was discussed in two dimensions as affective commitment and continuance commitment at first, normative commitment was added to the model later as the third dimension (Allen \& Meyer, 1990). Affective commitment means the emotional bond and high-level identification between employees and organization. Beyond all conditions, employees with high affective commitment continue to work in the organization only because they want to. Continuance commitment is related to the employee's awareness about the cost which will occur when the employee leaves the organization. The thought that the status and income obtained with the time, effort and energy that the employee has spent will be lost when he leaves the organization is the foundation of continuance commitment. The employee stays in the organization because he cannot risk the cost that leaving would cause. In normative commitment, the responsibility that the employee has towards the organization is dominant rather than personal interests. It is the type of commitment which occurs when the employees are loyal to the organization and continue to work in the organization due to the organization's investments and the opportunities it provides (Allen \& Meyer, 1990).

\subsection{Organizational Stress and Organizational Commitment}

Researches carried out indicate that there are positive relationships between organizational commitment and variables such as employee performances (Sarıdede \& Doyuran, 2004), internal motivation (Kara, 2015); job satisfaction (Demirtaş, 2010) and corporate responsibility perception (Serinikli, 2018). Positive relationship of organizational commitment with many variables which are vital for organizations supports acceleration of studies which affect organizational commitment negatively. As stress is a factor which affects individuals and organizations negatively, many researches were made on the relationship between organizational stress or work stress and organizational commitment.

The relationship between organizational commitment and stress can be explained with the approach developed by Salancik (1977). In his approach which defines organizational commitment in accordance with the behaviours of the organization member, Salancik (1977) stated that the harmony between the organization member's attitude and behaviours constitutes commitment and lack of harmony causes anxiety and stress in the member of the organization. Based on this approach, it can be said that there is a relationship between the individual's commitment to the organization and his stress level. 
Researches in which the relationship between employees' stress levels and organizational commitment is exhibited are carried out in different disciplines. In the researches in the field of health, Efeoğlu and Özgen (2007) exhibited that there is a weak positive relationship between job stress and organizational commitment; Ergün and Çelik (2015), Tekingündüz and Kurtuldu (2015) exhibited that there is a very weak negative relationship; Kılıç et al. (2008) exhibited that there is a weak negative relationship; Köseoğlu Şalk (2016) exhibited that there is a very weak positive relationship between organizational stress and the affective and normative commitment sub-dimensions of organizational commitment and there is a very weak negative relationship between continuance commitment; İncesu (2011) exhibited that there is a weak positive relationship between organizational stress and organizational commitment and Gül et al. (2008) exhibited that there is a very weak negative relationship between stress and organizational commitment. In studies carried out in the field of education, it was determined that there is a very weak negative relationship between job stress and organizational commitment (Güngör Seyhan, 2015; Yıldız, 2013) and also there is a very weak negative relationship between organizational stress and affective and normative commitment and a very weak positive relationship with continuance commitment (Aydoğan, 2008). In studies carried out in the field of tourism, Akpulat et al. (2016) determined that there is a very weak negative relationship and Pekerşen (2015) and Yiğit (2009) determined that there is a very weak positive relationship between job stress and organizational commitment and Düzgün (2014) determined that there is moderately positive relationship between organizational stress and organizational commitment. In studies carried out in the field of sports, Kaplan (2017) determined that there is a high positive relationship and Üzüm (2010) determined that there is a very weak negative relationship between organizational commitment and organizational commitment; in studies carried out in the field of banking, Turunç and Erkuş (2010) reported that there is a very weak negative relationship and Erdilek Karabay (2014) reported that there is a weak negative relationship between job stress and organizational commitment. In addition, it was exhibited that there is very weak negative relationship between organizational stress and organizational commitment in a study carried out in the field of media (İnan Yousuf, 2015); there is a weak positive relationship between job stress and job commitment in a study carried out in the field of maritime (Özdemir, 2017); there is a very weak negative relationship between job stress and organizational commitment in a study carried out in a private organization (Zincirkıran, Çelik, Ceylan \& Emhan, 2015) and there is a weak negative relationship between stress and organizational commitment in a study carried out in a public institution (Sökmen \& Şimşek, 2016).

When the studies conducted are reviewed, it is seen that some of the study results are positive and some of them are negative and even these conflicting results are in the same study field; while some of the results are very weak or weak, some of them are high in the study field; and some study results are similar. Therefore, this research is considered important as it serves as a guide for organizations and employees for comparing study results in the literature, obtaining a comprehensive result on the relationship between stress and organizational commitment levels of employees and increasing organizational commitment. In addition, since no other research investigating the relationship between these two variables with meta-analysis method could be found in the literature, the contribution it will provide to the literature is another aspect which makes this research important. For those reasons, this research aims to investigate the relationship between stress and organizational commitment levels of employees with meta-analysis method. Within the framework of this objective, answers are sought for the following questions:

1) What is the average impact size of the relationship between stress and organizational commitment in employees?

2) What is the average impact size of the relationship between stress and affective commitment, continuance commitment and normative organizational commitment in employees?

3) Does the relationship between stress and organizational commitment in employees vary according to the sector they work in?

\section{Method}

\subsection{Sample}

In the research, total number of sample of 13 studies on job stress and organizational commitment is 3.167, total number of sample of 8 studies on organization stress and organizational commitment is 1.434 and total number of samples of 1 study on stress and organizational commitment is 44 . Total number of sample of these 22 studies collected under the title of stress in employees is 4.645 .

\subsection{Data Collection Tools}

Within the scope of the research, studies which investigate the relationships between stress and organizational commitment variables in employees were used. During the process of determining these studies, databases such as YÖK (Council of Higher Education) thesis database, Google academics, Ulakbim (Turkish National Academic Network and 
Information Centre) and EBSCO host were used. These databases were reviewed two times on 02 July 2018 and 30 July 2018 and necessary examinations were made. Reviews were made in Turkish and English using keywords "stress", "organizational stress", "job stress" and "organizational commitment".

The criteria determined to include studies within the scope of the research: The research (a) is conducted on employees in Turkey, (b) includes correlation coefficient between organization stress, job stress and stress and organizational commitment variables in employees and sample size values, (c) is an article, master's or $\mathrm{PhD}$ thesis published between 2007 and 2018.

\subsection{Procedure}

The research is designed using meta-analysis method. Meta-analysis is a statistical method used for combining results in independent studies (Crombie \& Davies, 2009). In this method, data included in different studies is converted into a common measurement unit to be combined. This measurement unit is also called as impact size (Borenstein, Hedges, Higgins \& Rothstein, 2009). In the research, first correlation values were converted to Fisher $\mathrm{z}$ and analyses were made with converted values. While evaluating the analysis results, these values were interpreted by being converted to correlation coefficient. Cohen, Manion and Morrison (2007) classified correlation coefficient impact sizes as weak between \pm .00 and $\pm .10 ; \pm$ small between .10 and $.30 ; \pm$ moderate between .30 and .50 ; strong between \pm .50 and .80 and very strong over \pm .80 . The data obtained in the research was analysed using CMA statistic software.

Meta-analysis works are realized in six steps (Durlak, 1998). These steps are (i) identifying research questions, (ii) literature review, (iii) encoding works, (iv) impact size index, (v) statistical analysis of impact size distribution and (vi) deduction and conclusion.

By implementing the steps of meta-analysis studies, the researches on work stress, organizational stress and the relationship between stress and organizational commitment in employees in Turkey were encoded with the encoding form created and then related researches were combined with meta-analysis method. Correlations obtained from the studies were discussed in seven different meta-analyses as stress - organizational commitment in employees, stress affective commitment in employees, stress - continuance commitment in employees, stress - normative commitment in employees, stress-organizational commitment in healthcare employees, stress - organizational commitment in tourism employees and stress - organizational commitment in education employees.

Distribution of studies included in the meta-analysis according to years is shown in Table 1, their distribution according to the organizational sector are shown in Table 2 and distribution according to publication type is shown in Table 3.

Table 1. Distribution of studies according to years

\begin{tabular}{lcc}
\hline $\begin{array}{l}\text { Year in which the study } \\
\text { was carried out }\end{array}$ & Frequency & Percentage (\%) \\
\hline 2007 & 1 & 4.55 \\
2008 & 3 & 13.63 \\
2009 & 1 & 4.55 \\
2010 & 2 & 9.09 \\
2011 & 1 & 4.55 \\
2013 & 1 & 4.55 \\
2014 & 3 & 13.63 \\
2015 & 6 & 27.26 \\
2016 & 3 & 13.64 \\
2017 & 1 & 4.55 \\
\hline Total & 22 & 100
\end{tabular}

According to the data in Table 1, it is seen that researches were published between 2007 and 2017 and the maximum number of studies were published in $2015(n=6)$. 
Table 2. Distribution of studies according to organization sector

\begin{tabular}{lcc}
\hline $\begin{array}{l}\text { Sector in which study was carried } \\
\text { out }\end{array}$ & Frequency & Percentage (\%) \\
\hline Healthcare & 7 & 31.82 \\
Tourism & 5 & 22.73 \\
Education & 3 & 13.64 \\
Banking & 2 & 9.08 \\
Sport & 2 & 9.08 \\
Energy & 1 & 4.55 \\
Media & 1 & 4.55 \\
Public & 1 & 4.55 \\
\hline Total & 22 & 100
\end{tabular}

According to the data in Table 2, it is seen that the studies were mostly carried out in healthcare, tourism and education sectors.

Table 3. Distribution of studies according to publication type

\begin{tabular}{lcc}
\hline Publication type of the study & Frequency & Percentage (\%) \\
\hline Master's Thesis & 9 & 40.91 \\
\hline PhD Thesis & 2 & 9.09 \\
\hline Article & 11 & 50.00 \\
\hline Total & 22 & 100
\end{tabular}

According to the data in Table 3, it is seen that 12 of the studies are articles and 10 are theses. The research did not include the papers presented in related symposium or congresses, studies carried out abroad and studies with publication restriction. Studies included in analysis in the research are indicated with () symbol in the references.

\subsection{Validity and Reliability}

In meta-analysis, validity is examined in two parts as internal and external validity. Internal validity is related to the use of appropriate data collection and analysis methods, and external validity refers to the extent to which the studies achieved represent the universe. For meta-analysis to be reliable, at least 30 studies should be reached in relational studies (DeCoster, 2004). According to these explanations, it can be said that the research is valid and reliable.

\subsection{Publication Bias Analyses}

It can also be determined if there is any publication bias in the meta-analysis studies by using cone chart (Dinçer, 2014). The cone chart obtained as a result of analvses conducted for this purbose is given in Figure 1.

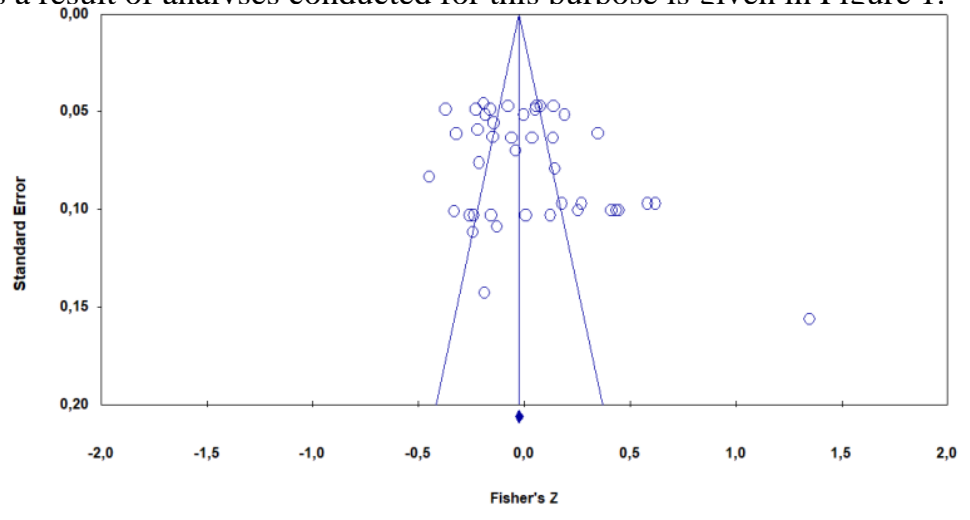

Figure 1. Cone chart of the studies 
According to the cone chart in Figure 1, it can be said that studies are mostly in the top of the cone and therefore the sample sizes are big in general. In addition, it was determined that Tau coefficient is .24 and $\mathrm{p}$ value is .48 in the analyses. When the data obtained is examined, it can be said that the study does not have publication bias as Tau coefficient is close to 1 and $\mathrm{p}$ value does not create a significant difference and symmetric distribution is seen on both sides of the general impact line in the middle of cone chart.

\section{Results}

42 comparisons in 22 studies in which the relationship between stress and organizational commitment is investigated in employees in Turkey are included in the research. Impact coefficients of the meta-analysis study conducted with the research group are given in Table 4.

Table 4. Impact coefficients of the meta-analysis study

\begin{tabular}{|c|c|c|c|c|}
\hline Title of the Study & $\begin{array}{l}\text { Organizational } \\
\text { Commitment }\end{array}$ & Sample Size & Correlation & Fisher's Z \\
\hline Akpulat ve ark. 2016 & general & 324 & -0.142 & -0.143 \\
\hline Aydoğan 2008 & continuance & 378 & 0.190 & 0.192 \\
\hline Aydoğan 2008 & affective & 378 & -0.180 & -0.182 \\
\hline Aydoğan 2008 & normative & 378 & -0.003 & -0.003 \\
\hline Efeoğlu, Özgen 2007 & general & 162 & 0.144 & 0.145 \\
\hline Erdilek Karabay 2014 & general & 268 & -0.309 & -0.319 \\
\hline Ergün, Çelik 2015 & general & 286 & -0.216 & -0.219 \\
\hline Gül et al. 2008 & general & 87 & -0.129 & -0.130 \\
\hline Güngör Seyhan 2015 & general & 52 & -0.184 & -0.186 \\
\hline Kılıç ve ark. 2008 & general & 101 & -0.319 & -0.331 \\
\hline Pekerşen 2015 & continuance & 449 & 0.138 & 0.139 \\
\hline Pekerşen 2015 & continuance & 449 & 0.077 & 0.077 \\
\hline Pekerşen 2015 & general & 449 & 0.059 & 0.059 \\
\hline Pekerşen 2015 & normative & 449 & -0.076 & -0.076 \\
\hline Tekingündüz, Kurtuldu 2015 & general & 208 & -0.041 & -0.041 \\
\hline Turunç ve Erkuş 2010 & general & 175 & -0.210 & -0.213 \\
\hline Y1ld1z 2013 & continuance & 423 & 0.053 & 0.053 \\
\hline Y1ldız 2013 & affective & 423 & -0.354 & -0.370 \\
\hline Y1ldı 2013 & general & 423 & -0.224 & -0.228 \\
\hline Y1ldiz 2013 & normative & 423 & -0.158 & -0.159 \\
\hline Zincirkıran ve ark. 2015 & general & 254 & -0.146 & -0.147 \\
\hline Düzgün 2014 & continuance & 109 & 0.524 & 0.582 \\
\hline Düzgün 2014 & continuance & 109 & 0.264 & 0.270 \\
\hline Düzgün 2014 & affective & 109 & 0.177 & 0.179 \\
\hline Düzgün 2014 & general & 109 & 0.552 & 0.621 \\
\hline İnan Yousuf 2015 & general & 83 & -0.238 & -0.243 \\
\hline İncesu 2011 & affective & 102 & 0.390 & 0.412 \\
\hline İncesu 2011 & general & 102 & 0.420 & 0.448 \\
\hline İncesu 2011 & normative & 102 & 0.409 & 0.434 \\
\hline İncesu 2011 & continuance & 102 & 0.250 & 0.255 \\
\hline Kaplan 2017 & general & 44 & 0.874 & 1.350 \\
\hline Köseoğlu Şalk 2016 & continuance & 251 & -0.059 & -0.059 \\
\hline Köseoğlu Şalk 2016 & affective & 251 & 0.037 & 0.037 \\
\hline Köseoğlu Şalk 2016 & normative & 251 & 0.135 & 0.136 \\
\hline Şahin 2014 & general & 269 & 0.335 & 0.348 \\
\hline Üzüm 2010 & General & 479 & -0.190 & -0.192 \\
\hline Yiğit 2009 & continuance & 97 & 0.123 & 0.124 \\
\hline Yiğit 2009 & continuance & 97 & 0.009 & 0.009 \\
\hline Yiğit 2009 & affective & 97 & -0.233 & -0.237 \\
\hline Yiğit 2009 & General & 97 & -0.154 & -0.155 \\
\hline Yiğit 2009 & Normative & 97 & -0.254 & -0.260 \\
\hline Sökmen ve Şimşek 2016 & General & 147 & -0.420 & -0.448 \\
\hline
\end{tabular}

It is seen in Table 4 that the number of individuals included in the study groups of the researches vary between 44 and 479 and correlation coefficients vary between -0.420 and 0.874 .

In meta-analysis studies; the course of the process is coding, calculation of impact coefficients, heterogeneity test and calculation of the overall impact. For that reason, heterogeneity analysis was conducted in the third stage of the research and data was given in Table 5 . 
Table 5. Heterogeneity test meta-analysis results

\begin{tabular}{ccccc}
\hline Heterogeneity & df & Average Effect & $95 \%$ CI & P \\
\hline Q 534. 390 & 41 & E++ -.024 & $-.044--.004$ & .00
\end{tabular}

In heterogeneity test data, it is seen that $\mathrm{Q}=534.390, \mathrm{p}=.00$. Since $\mathrm{p}$ value is smaller than .05 and larger than the value which correspond to df value of $\mathrm{Q}$ value on $\chi^{2}$ chart $(\mathrm{Q}=66.766)$, it can be said that meta-analysis application has a heterogeneous nature. Therefore, the analyses were repeated with the random effects model. In the analysis with random effects model, it is seen that the weight of the data is between -.50 and .50 in general and in other words, their contribution in overall impact is close to each other. In addition, overall impact coefficient of these studies, the correlation coefficients of which are between -.420 and .874 according to Fisher $z$, is calculated as $(r=.026, p>.05)$. This result can be evaluated as positive and weak impact size.

It is seen that researches on stress in employees generally concentrate under the titles of work stress or organizational stress in general. In the analyses within the scope of the research, these studies were combined under the title of stress in employees. Table 6 contains data obtained from analyses conducted.

Table 6. Stress in employees' meta-analysis results according to random effects model

\begin{tabular}{lcccc}
\hline Heterogeneity & $\mathrm{df}$ & Average Effect & 95\% CI & $\mathrm{p}$ \\
\hline Stress in Employees Q 534.390 & 42 & E++.026 & $-.048-.100$ & .48 \\
Stress in Employees - Affective Commitment Q 72.378 & 6 & E++-.034 & $-.243-177$ & .75 \\
Stress in Employees - Continuance Commitment Q 12.716 & 4 & E++. .100 & $-.025-.222$ & .11 \\
Stress in Employees - Normative Commitment Q 41.379 & 6 & E++.006 & $-.137-.149$ & .93
\end{tabular}

According to Table 6, in the research it was determined that data obtained from 22 studies on stress in employees is between -.048 and .100 limits in $95 \%$ confidence interval with $\mathrm{df}=42$ degree of freedom, $\mathrm{p}$ value is larger than .05 and average impact size is positive. In other words, it can be said that there is no significant difference between stress and organizational commitment relationship averages in employees and stress has a positive relationship impact on organizational commitment in employees. In consideration of the impact size $(\mathrm{E}++=.026)$, impact coefficient was determined as weak. In addition, it can be expressed that there is weak negative relationship between stress and affective commitment (E++ -.034); positive and weak relationship between stress and normative commitment (E++ .006) and positive and small relationship between stress and continuance commitment $(\mathrm{E}++.100)$ in employees.

In the research, it is seen that the research conducted to determine how the impact of stress on organizational commitment in employees vary according to the sector they work has intensified; meta-analysis is conducted also with health $(\mathrm{n}=7)$, tourism $(\mathrm{n}=5)$ and education $(\mathrm{n}=3)$ sectors and average impact size is $(\mathrm{E}++=.085)$ in health, $(\mathrm{E}++=.101)$ in tourism and $(\mathrm{E}++=-.107)$ in education. Results obtained as a result of analyses conducted are given in Table 7.

Table 7. Employees' organization sector analysis results according to random effects model

\begin{tabular}{lcccc}
\hline Heterogeneity & df & Average Effect Size & $95 \%$ CI & $\mathrm{p}$ \\
\hline Healthcare Q 92.799 & 12 & E++.085 & $-.045-.213$ & .19 \\
Tourism Q 136. 543 & 15 & E++.101 & $-.010-.210$ & .74 \\
Education Q 87.166 & 8 & E++-.107 & $-236-.025$ & .11
\end{tabular}

According to Table 7, it can be said that impact coefficients calculated are positive in health and education and negative in education; according to the classification of Cohen et al. (2007), a weak impact size is seen in heath and a small impact size is seen in tourism and education.

\section{Discussion}

This study aims to exhibit the relationship between stress and organizational commitment in employees with meta-analysis method. To achieve this objective, results of 22 studies in total from different sectors such as health, tourism, education, banking, energy and sports were examined and the impact size of stress on organizational commitment in employees is calculated and an overall impact size coefficient is obtained. In addition, results of researches in which organizational commitment is discussed as affective commitment, normative commitment and continuance commitment were also used and the impact size of stress on these sub-dimensions was calculated. Moreover, considering that this impact size may vary according to the sector; health, tourism and education sectors with the most intense work were discussed separately. However, this research has the restrictions which occur in many meta-analysis 
studies. These can be listed as the restriction of search engines and electronic databases, publications blocked by researchers and not defining the sample group clearly in the researchers.

In this research, it was concluded that stress has a weak positive relationship impact on organizational commitment in employees. Stress affecting organizational commitment positively can be explained with the second phase of general adaptation syndrome. In employees who experience stress, first reactions to the source of stress are formed and these reactions are accompanied by physiologic changes. When the duration of exposure to the cause of stress is extended, employees resist to the cause of stress and struggle actively to eliminate the imbalance caused by the stress (Ross \& Altmaier, 1994). Employees' active behaviours to get rid of the imbalance caused by stress may affect their organizational commitment positively and stress may undertake a role of increasing organizational commitment. On the other hand, although the relationship between stress and organizational commitment is positive in employees, its weak level can be explained by the fact that stress causes become chronic and employees become insensitive to these causes due to the possibility that individuals may encounter a factor which cause stress at any time in daily work life. As a result of this insensitivity, individuals continue their work under even excessive stress and their organizational commitment is not heavily affected by this stress. In addition, this result of the research is compatible with other study results (Efeoğlu \& Özgen, 2007; İncesu, 2011; Özdemir, 2017; Pekerşen, 2015; Yiğit, 2009).

In this study, it was also concluded that there is weak negative relationship between stress and affective commitment; weak positive relationship between stress and normative commitment and small positive relationship between stress and continuance commitment in employees. Similar to this result, Meyer et al. (2002) reported that affective commitment is negatively related to stress and work-family conflict, but continuance commitment is positively related to both variables in their meta-analysis study on organizational commitment. Researchers stated that they encountered very few studies to calculate the relationship between normative commitment and stress. That stress affects only affective commitment negatively among organizational commitment sub-dimensions can be explained by the fact that stress is an emotional concept. Employees who have high affective commitment levels have also high levels of integration with the organization, making an effort towards organizational objectives and willingness to contribute in the organization (Allen \& Meyer, 1990). However, affective commitment of employees who cannot go into balance state against stress and start exhaustion may be more easily affected by this situation in a negative manner and this negative impact may cause that affective commitment levels of the employees decrease. Therefore, employees who are exposed to causes of stress may exhibit behaviours in the direction of breaking emotional ties which enable integration and identifying with the organization. In addition, many researches (Aydoğan, 2008; Yıldız, 2013; Yiğit, 2009) verify that there is a negative relationship between stress and affective commitment in employees. On the other hand, stress has a positive impact on normative and continuance commitments of employees. Employees with high normative commitment level have emotions such as being responsible, feeling liability, being loyal and being grateful to the organization. Employees' worrying about fulfilling their responsibilities and liabilities as a result of the pressure that stress causes on employees may affect their normative commitment levels positively. Positive relationship between stress and normative commitment is a result which is also verified in different researches (İncesu, 2011; Köseoğlu Şalk, 2016). In continuance commitment, personal interests are in the forefront unlike moral beliefs in normative commitment. Employees cannot risk the losses that leaving the organization will cause. For that reason, stress affects continuance commitment more compared to normative commitment. As the stress level increases, an increase may be observed in the continuance commitment of employees who are afraid to lose what they have. This result is also compatible with other research results (Aydoğan, 2008; Düzgün, 2014; İncesu, 2011; Pekerşen, 2015; Y1ldız, 2013; Yiğit, 2009).

Another result of this study is that impact of stress on organizational commitment is positive and weak in the field of health. While the fact that this impact is positive in the field of health can be explained by the second phase of general adaptation syndrome as mentioned above, its being weak is quite interesting. Because, the field of health includes profession groups in which stress occurs most intensively. The sample of the studies reviewed in the field of health consists of nurses (Ergün \& Çelik, 2015; Köseoğlu Şalk, 2016) and all healthcare personnel described as doctors, administrative/technical personnel, nurses, midwives and emergency medical technicians (Tekingündüz \& Kurtuldu, 2015). However, in other studies (Gül et al., 2008; İncesu, 2011; Kılıç, Efeoğlu, Mimaroğlu \& Özgen, 2008) the sample was defined as healthcare personnel, but who the healthcare personnel include is not mentioned. Sample of the study of Efeoğlu and Özgen (2007) consists of regional coordinator, regional director and medical representatives working at 66 pharmaceutical companies. The possibility that sample is selected from healthcare professionals who have lower exposure levels to stress in many studies may explain the weak relationship between stress and organizational commitment in the field of health. However, the fact that healthcare professionals have high insensitivity to stress as stress is intense in the field of health may also be the cause of this weak relationship. As a result of this insensitivity, healthcare professionals are not affected by causes of stress and the impact of stress on their organizational commitment may remain weak. In addition, this result of the study verifies other study findings (Efeoğlu \& Özgen, 2007; İncesu, 2011) as well. 
Another result of this study is that impact of stress on organizational commitment is small and positive in the field of tourism. Tourism is also one of the sectors where causes of stress occur intensively. The study by Sökmen (2005) exhibited that especially long working hours and customers' different and sometimes impossible or unfair demands create stress on tourism employees. That the relationship between stress and organizational commitment is small in this study may be caused by sample selection. While the sample in the study by Pekerșen (2015) consists of cooks, the sample of the study by Yiğit (2009) consists of middle level managers, the sample of the study by Düzgün (2014) consists of top level managers and the sample of the study by Şahin (2014) consists of travel agency employees. In the sample selection by Akpulat et al. (2016), a general expression of tourism employees was used and who these tourism employees are is not explained. Top level and middle level managers and travel agency employees, who constitute the majority of the sample, may not be exposed to causes of stress as much as employees who face customers at any time in tourism. The fact that stress does not form intensively may cause that its impact on organizational commitment is small. In addition, the positive relation between stress and organizational commitment may be caused by the fact that tasks causing stress are challenging and emotions such as happiness, superiority and difference that occur when these challenging tasks are achieved. While intensive demands may be a cause of stress in tourism which is a service sector, fulfilling these demands effectively may bring employees to a prioritized position in their workplaces and this position may affect organizational commitment in a positive manner. In addition, other researches (Pekerşen, 2015; Yiğit, 2009) confirm that there is a weak positive relationship between stress and organizational commitment in employees.

In this study, it was also concluded that the impact of stress on organizational commitment is small and negative in the field of education. Although stress affects organizational commitment positively in the fields of health and tourism, this impact is negative in education. The cause of this negative impact can be explained by the fact that study samples in the field of education consists of teachers only. Teachers, who are the building blocks of education-teaching activities, are obliged to fulfil many tasks and responsibilities. Main tasks of teachers can be listed as teaching, administrative and management task, professional/specialty task and student consultancy task (Özdemir, Yalın \& Sezgin, 2012). Competence fields are gathered under three main titles as professional knowledge, professional skill and attitude and values. Teachers' having tasks and responsibilities in many different processes may cause that they are exposed to stress more frequently and intensively and that they cannot go into balance state against this intensive stress cause that they experience exhaustion and it can be said that this exhaustion affects organizational commitment in a negative manner (Demirel, Tohum \& Kartal, 2017).

Study results indicate that stress may have a positive impact on organizational commitment. For example, Robbins and Judge (2015) state that stress is not completely bad, it is also an opportunity when it provides potential gains. They discuss stress in two parts as encouraging causes of stress; work load, pressure to complete tasks, urgency and preventive causes of stress; paperwork, workplace policies, responsibility complexity, etc. In addition, they also mention that encouraging causes of stress cause less tension than preventive causes of stress. Based on the view of Robbins and Judge (2015), it can be said that causes of stress in employees should be investigated on the basis of organizations and a contribution may be provided in organizational commitment of employees by means of the power of encouraging causes of stress.

Due to the negative impact of stress on affective commitment in employees; organizational features (organizational policy, organizational structure, organizational process), work demand and role features (working conditions, personal relationships, work demand and role features) and personal features (career concern and personal factors) which cause preventive stress in work life may be investigated on sector basis and each sector may develop suitable solutions for preventing harmful impact of stress in accordance with the results obtained. Due to the positive impact of stress on normative commitment and continuance commitment; tasks and responsibilities which are challenging and improving their potentials may be assigned to the employees and encouraging causes of stress may be used.

Since the impact of stress on organizational commitment exhibit sectorial differences in the results of the research, investigations may be conducted at certain intervals on factors such as organizational structure and climate, physical environment conditions, work done, career development and relationships within the organization which may cause stress in different sector employees; participative management system may be realized; activities may be carried out to determine objectives; role analysis and classification may be done; emotional climate controls may be done; time management and stress management trainings may be given to the employees and social support may be provided (Özkalp \& Krel, 2016). Thus, stress levels of the employees may be determined and a contribution may be provided in reducing stress and increasing affective commitments in sectors where stress is high.

\section{References}

Ahmed, A., \& Ramzan, M. (2013). Effects of job stress on employees job performance a study on banking sector in Pakistan. IOSR Journal of Business and Management, 11(6), 61-68. https://doi.org/10.9790/487X-1166168

Akhtar, M. M. S. (2011). The nature and sources of organizational stress: Some coping strategies. Journal Elementary Education, 21(2), 1-14. 
Akınaltuğ, E. (2003). An analysis of the relationship between job stress, job satisfaction and organizational commitment in managers: Tedaş example (Unpublished Master's Thesis). Kırıkkale University Social Sciences Institute, Kirikkale.

Akpulat, A. N., Polat, Ü. T., \& Karacan, E. (2016). The relationship between job stress and organizational commitment of the employees working in the tourism busineses; the case of Çeşme and Kartepe. Journal of Human Sciences, 13(3), 5136-5149. https://doi.org/10.14687/jhs.v13i3.4192

Allen, N. J., \& Meyer, J. P. (1990). The measurement and antecedents of affective, continuance, and normative commitment to the organization. Journal of Occupational Psychology, 63, 1-18. https://doi.org/10.1111/j.2044-8325.1990.tb00506.x

Aydoğan, O. (2008). The relationship between job stress and burnout and organizational commitment is an application in the public sector (Unpublished Master's Thesis). Turkish Military Academy Defense Sciences Institute, İstanbul.

Balc1, A. (2003). Organizational socialization theory strategies and tactic. Ankara: Pegem A.

Baltaş, Z., \& Baltaş, A. (2004). Stress and ways of coping. İstanbul: Remzi.

Bertan, B. (2012). The relationship between organizational stress and organizational commitment of school principals working in public-private primary schools (Pendik case) (Unpublished Master's Thesis). Yeditepe University Institute of Social Sciences, Istanbul.

Bhagat, R. S., Krishnan, B., Nelson, T. A., Leonard, K. M., Ford, D. L., \& Billing, T. K. (2010). Organizational stress, psychological strain, and work outcomes in six national contexts. Cross Cultural Management: An International Journal, 17, 10-29. https://doi.org/10.1108/13527601011016880

Borenstein, M., Hedges, L. V., Higgins, J. P. T., \& Rothstein, H. R. (2009). Introduction to meta analysis. Cornwall: John Wiley \& Sons. https://doi.org/10.1002/9780470743386

Buchanan, B. (1974). Building organizational commitment: The socialization of managers in work organizations. Administrative Science Quarterly, 19, 533-546. https://doi.org/10.2307/2391809

Caught, K., \& Shadur, M. A. (2000). The measurement artifact in the organizational commitment questionnaire. Psychological Reports, 87, 777-788. https://doi.org/10.2466/pr0.2000.87.3.777

Celep, C. (2000). Organizational commitment of teachers in educational organizations. Ankara: An1.

Cohen, L., Manion, L., \& Morrison, K. (2007). Research methods in education (6th Edition). Routledge, Canada. https://doi.org/10.4324/9780203029053

Crombie, I. K., \& Davies H. T. O. (2009). What is meta-analysis? London: Hayward Medical Communications.

Cüceloğlu, D. (1998). Human and their behavior. İstanbul: Remzi.

De Cotiis, T. A., \& Summers, T. P. (1987). A path analysis of a model of the antecedents and consequences of organizational commitment. Human Relations, 40(7), 445-470. https://doi.org/10.1177/001872678704000704

DeCoster, J. (2004). Meta-analysis notes. Department of Psychology, University of Alabama.

Demirel, Y., Tohum, E. U., \& Kartal, Ö. (2017). The effect of burnout on organizational commitment: A study on nurses in a unversity hospital. Kastamonu University Journal of faculty of Economics and Administrative Sciences, 18(1), 442-459.

Demirtaş, H. (2010). The organizational commitment and job satisfaction among teachers working at private courses. Inonu University Journal Of The Faculty Of Educatıon, 11(2), 177-206.

Dinçer, S. (2014). Applied meta-analysis in educational sciences. Ankara: Pegem Akademi

Durlak, J. (1998). Understanding meta-analysis. In L. G. Grimm \& P. R. Yarnold (Eds.). Reading and understanding multivariate statistics (pp. 319-352). Washington DC: American Psychological Association.

Düzgün, A. (2014). Analysis of the relationship between organizational stress and organizational commitment in senior executives: An application in the five-star hotel business in the Antalya region. (Unpublished Master's Thesis). Adnan Menderes University Institute of Social Sciences, Aydın.

Efeoğlu, İ. E., \& Özgen, H. (2007). The effects of work family conflict on job stres, job satısfaction and organizational commitment: A study in the pharmaceutıcal industry. Journal of Çukurova University Institute of Social Sciences, 16(2), 237-254.

Erdilek, K. M. (2014). An investigation of the effects of workrelated- stress and organizational commitment on organizational citizenship behavior: A research on banking industry. Journal of Business Research-Türk, 6(1), 282-302. https://doi.org/10.20491/isader.2014115975

Ergün, E., \& Çelik, S. (2015). Managers' task-oriented and employee-oriented leadership behaviors: Effects on nurse 
job satisfaction, organizational commitment and job stress. Florence Nightingale Nursing Journal, 23(3), 203-214.

Etzioni, A. (1961). A Comparative analysis of complex organizations. New York: Free Press.

Folkman, S., Lazarus, R., Gruen, R., \& DeLongis, A. (1986). Appraisal, coping, health status, and psychological symptoms. Journal of Personality and Social Psychology, 50, 571-579. https://doi.org/10.1037/0022-3514.50.3.571

Gharib, M., Jamil, S., Ahmed, M., \& Ghouse, S., (2016). The impact of job stress on job performance: A case study on academic staff at dhofar university. International Journal of Economic Research, 13(1), 21-33.

Gül, H., Oktay, E., \& Gökçe, H. (2008). Relations between job satisfaction, stress, organizational commitment, intention to leave and performance: an application in the health sector. Academic Review International Refereed Journal of Social Sciences, 15, 1-11.

Güngör, S. H . (2015). Analysis on job satisfaction, self-efficacy perception, organizational commitment and work stress levels of chemistry teachers's with respect to diverse variables. Turkish Journal of Education, 4(2), 41-60. https://doi.org/10.19128/turje.181114

İnan, Y. N. (2015). Relationship between organizational stress and organizational commitment and research. (Unpublished Master's Thesis) Istanbul University, Institute of Social Sciences, Istanbul.

İncesu, Z. (2011). The role of organizational stress sources in the normative, emotional and continuity commitment of employees. (Unpublished Master's Thesis). Muğla S1tkı Koçman University Institute of Social Sciences, Muğla.

Kaplan, B. (2017). Determination of organizational commitment and organizational stress levels of physically disabled paralympics (Unpublished Master's Thesis) Istanbul University Institute of Health Sciences, Istanbul.

Kara, Z. (2015). The effect of organizational commitment levels on employee motivation and a research (Unpublished Master's Thesis). Eskişehir Osmangazi University Institute of Social Sciences, Eskişehir.

Khatibi, A., Asadi, H., \& Hamidi, M. (2009). The relationship between job stress and organizational commitment in National Olympic and Paralympic Academy. World Journal of Sport Sciences, 2(4), 272-278.

Kılıç, C., Efeoğlu, İ. E., Mimaroğlu, H., \& Özgen, H. (2008). A study on the effect of work-family conflict of life on organizational commitment, job satisfaction and job stress of staff working in private health centers in Adana province Journal of Çukurova University Institute of Social Sciences, 17(2), 241-254.

Köseoğlu, Ş. Y. (2016). The mediating role of the organizational stress in the relationship between nurses' job satisfaction and organizational commitment: An investigation in the province of Muğla (Unpublished Master's Thesis). Atatürk University Institute of Social Sciences, Erzurum.

Lazarus, R. S., \& Folkman, S. (1984). Stress, appraisal and coping. New York: Springer

Magnuson, J. (1990). Stress management. Journal of Property Management, 55(3), $24-26$.

Manning, D., \& Preston, A. (2003). Organizational stress: Focusing on ways to minimize distress. CUPA-HR Journal, $54,15-18$.

Meyer J., Becker, T., \& Vandenberghe, C. (2004). Employee commitment and motivation: A conceptual analysis and integrative model. Journal of Applied Pschology, 89(6), 991-1007. https://doi.org/10.1037/0021-9010.89.6.991

Meyer, J. P., \& Allen, N. J. (1984). Testing the "side-bet theory" of organizational commitment: Some methodological considerations. Journal of Applied Psychology, 69(3), 372-378. https://doi.org/10.1037/0021-9010.69.3.372

Meyer, J., \& Allen, N. (1997). Commitment in the workplace, theory research and application. Thousand Oaks, CA: Sage.

Meyer, J., Stanley, D., Herscovitch, L., \& Topolnytsky, L. (2002). Affective, continuance and normative commitment to the organization: A meta analysis of antecedents, correlates and consequences, Journal of Vocational Behavior, 61(1), 20-52. https://doi.org/10.1006/jvbe.2001.1842

OReilly, C. A., \& Chatman, J. A. (1986). Organizational commitment and psychological attachment: The effects of compliance, identification and internalization on prosocial behavior. Journal of Applied psychology, 71, 492-499. https://doi.org/10.1037/0021-9010.71.3.492

Özdemir, İ. (2017). The role of job loyalty in the relationship between work stress and work life balance: A research on shipmen (Unpublished Master's Thesis). Marmara University Institute of Social Sciences, Istanbul.

Özdemir, S., Yalın, H. İ., \& Sezgin, F. (2008). Introduction to educational science (6. Baskı). Ankara: Nobel.

Özkalp, E., \& Kırel, Ç. (2016). Organizational behavior. Bursa: Ekin

Palmer, S., Cary, C., \& Kate, T. (2003). Model of organizational stress. Health Education Journal, 6, 378-380.

Pekerşen, Y. (2015). The relationship between job stress, job satisfaction, organizational commitment and toxic 
behavior of chefs working in hotels. (Unpublished PhD Thesis). Mersin University Institute of Social Sciences, Mersin.

Robbins, S. P., \& Judge, T. A. (2015). Organizational behavior. Çev. Edit.: Erdem, İ. 14. Basımdan çeviri. Ankara: Nobel

Ross, R. R., \& Altmaier, E. M. (1994). Intervention in occupational stress. London: SAGE.

Ross, R. R., \& Altmaier, E. M. (1994). Intervention in occupational stress. London: SAGE.

Şahin, B. (2014). Research on the Relation between Organizational Stress and Organizational Commitment of Travel Agency Employees: The Case of Istanbul . Balikesir University Journal of Social Sciences Institute, 17(32), 193-210.

Salancik, G. R. (1977). Commitment and the control of organizational behavior and belief. InB. M. Staw \& GR Salancik (Eds.), New directions in organizational behavior: 1-54. Chicago: St.

Sarıdede, U., \& Doyuran, Ş. (2004, July). The effect of organizational commitment on intention to quit in educational organizations. 13th National Educational Sciences Congress, Inonu University Faculty of Education, Malatya.

Selye, H. (1980). A personal message from Hans Selye. Journal of Extension, 18(3), 6-11.

Serinikli, N. (2018). The relationship between employees' corporate social responsibility perceptiğon and organizational commitment. Pamukkale University Journal of Social Sciences Institute, 31, 285-301. https://doi.org/10.30794/pausbed.414966

Sökmen, A., \& Şimşek, T. (2016). The relationship between organizational commitment, organizational identification, stress and turnover intention: Research in a public company. Gazi University Journal of Economics and Administrative Sciences, 18(3), 606-620.

Stinchcomb, J. B. (2004). Police stress: Could organizational culture be the culprit. Paper presented at the Law Enforcement Executive Forum, 4(3) 151-163.

Sullivan, S. E., \& Bhagat, R. S. (1992). Organizational stress, job satisfaction and job performance: Where do we go from here? Journal of Management, 18, 353-374. https://doi.org/10.1177/014920639201800207

Tekingündüz, S., \& Kurtuldu, A. (2015The analysis of relationship between intention to leave, job satisfaction, organizational commitment, leadership and job stress: A hospital example. International Journal of Human Sciences, 12(1), 1501-1517. https://doi.org/10.14687/ijhs.v12i1.3270

Turunç, Ö., \& Erkuş, A. (2010). The effects of work-family life conflict on job satisfaction and organizational commitment: The mediating role of work stress. Selçuk University The Journal of Social Economic Research, 13(19), 415-440.

Tutar, H. (2000). Crisis and stress management. İstanbul: Hayat.

Ünsal, P. (2012). The perception of job stress and the role of individual differences in coping. Aşkın Keser, Gözde Yılmaz, Senay Yürür (Eds.) In Behavior in Working Life: Current Approaches (p. 387-422) İzmit: Umuttepe

Üzüm, H. (2010). An investigation over the relationship between stress level and organizational commitment for elite athletes. (Unpublished PhD Thesis) Abant İzzet Baysal University, Institute of Social Sciences, Bolu.

Wiener, Y. (1982). Commitment in organizations: A normative view. Academy of Management Review, 7(3), 418-428. https://doi.org/10.5465/amr.1982.4285349

Yiğit, E. (2009). Relationship between organizational stress and organizational commitment: A study on mid-level hotel managers. (Unpublished Master's Thesis). Eskisehir Osmangazi University Institute of Social Sciences, Eskisehir.

Yıldiz, B. (2013). Analyzing the perception of primary and secondary school teachers on job stress, organizational commitment and job satisfaction. (Unpublished Master's Thesis). Maltepe University Institute of Social Sciences, Istanbul.

Zincirkıran, M., Çelik, G. M., Ceylan, A. K., \& Emhan, A. (2015). The effect of organizational commitment, job turnover, job stress and job satisfaction on organizational performance: a case study on the energy sector. Finans Politik \& Ekonomik Yorumlar, 52(600), 59-71.

\section{Copyrights}

Copyright for this article is retained by the author(s), with first publication rights granted to the journal.

This is an open-access article distributed under the terms and conditions of the Creative Commons Attribution license which permits unrestricted use, distribution, and reproduction in any medium, provided the original work is properly cited. 